\title{
Albanian Myths and Custom Law in Literature
}

\author{
Dhurata Lamçja
}

\section{Abstract}

Mythology plays a very important role in the general culture of the Albanian people, and the influence of the latter is undoubtedly seen in the later literature, developed in different historical periods, while mythology is taken as an important basis for a series of canons both in a structural manner as well as with the inclusion of a number of literary figures. Albanian mythology consists of a complete and diverse catalog of cults and beliefs which together have developed into a rich treasure which from time to time has inspired later Albanian writers, from the Middle Ages to modern ones. This article serves as pamphlet which explains the Albanian mythology in bold lines, including the main constituent elements of this mythology, the impact that this mythology has had on the daily customary life of the Albanian people, as well as the inevitable impact that the latter has had on the literature of the country.

Keywords: Albanian Myths, Custom Low, Literature

\section{Introduction}

\section{Albanian mythology}

Myths are narrative narratives that present the connection of the natural with the supernatural, with the cult of deities, but also of cultural heroes, with the supernatural origin of objects and phenomena of the real world (Tirta, 2004). Myths show the secret origin or metamorphosis of many phenomena and are closely related to the belief in hidden and incomprehensible forces, in demons and deities (Tirta, 2004).

Myths, together with the customs, rituals, legends, and tales of the Albanian people, constitute the Albanian folk beliefs (Georges \& Jones, 1995). Elements of Albanian mythology are of Paleo-Balkan origin, and almost all have a pagan character (Bonnefoy, 1993). Albanian folklore evolved over the centuries into a relatively isolated tribal culture and society (Elsie, 2001). Albanian folk tales and legends have been passed down through the generations and are still very much alive in the mountainous regions of Albania, Kosovo, the southern part of Montenegro, and the western part of Northern Macedonia as well as between the Arbëresh in Italy and the Arvanites in Greece (Elsie, 2001).

In Albanian mythology, supernatural beings take on the attributes of physical phenomena, elements, and objects (Misiri, 2015). Deities are generally not persons, 
but personifications of nature, which is known as Animism (Bonnefoy, 1993). As far as cults are concerned, the earliest proven one is the worship of the Sun and the Moon (Elsie, 2001). In Albanian folk beliefs, the earth is the object of a particular cult. Also, an important role is played by fire, which is considered a living, sacred or divine element used for rituals, sacrificial offerings, and purification (Bonnefoy, 1993). Fire worship is associated with the cult of the Sun, the cult of the hearth, and the cult of fertility in agriculture and livestock (Tirta \& Bezhani, 2004). Also, Besa is a common practice in Albanian culture, consisting of an oath made by the Sun, the Moon, the sky, the earth, the fire, the stone, the mountain, the water, and the serpent, which are considered to be all sacred objects (Tirta \& Bezhani, 2004). The cult of the Sun and the Moon has appeared in Albanian folk legends and art (Elsie, 2001).

Albanian myths and legends are organized around the dichotomy of good and evil (Elsie, 1994), whose most famous representation is the legendary battle between the Dragon and the cub (Bonnefoy, 1993), a conflict that symbolizes the cyclical return to the world of death, fulfilling the cosmic renewal of the renaissance. The weavers of fate, the orë or fate, control the order of the universe and enforce its laws (Doja, 2005). A prevalent motif in Albanian folklore is the metamorphosis: men turn into deer, wolves, owls, while women turn into tulip brides, cuckoos, turtles. Among the most famous Albanian folk poems, we mention "Këngët e Kreshnikëve," the traditional nonhistorical cycle of Albanian epic songs, based on the cult of the legendary hero (Bonnefoy, 1993).

\section{Cults as part of Albanian mythology}

A primary aspect in the field of mythology is the examination of myths, rites, and beliefs related to objects, places, and various natural phenomena in the Albanian people. In the case of Albanian mythology, many incredible legends, characters, and stories have been passed down from generation to generation or have been included in history books. In them are revealed the early worship and devotion to particular figures or objects, which take the name of cults.

The cult of nature is one of the pagan cults where places, objects, animals, and extraordinary shocking phenomena, or the quietest periodic changes in nature, were clothed with supernatural qualities, woven with enigmas (Tirta, 2004). Depending on their whims and desires, these places, objects, animals, and natural phenomena could do good or bad to people. For this reason, they had to be dealt with well through prayers, ceremonies, sacrifices, and taboos dedicated to places of worship and places of worship. The cult of myriads and springs is the most preserved among the cults of nature. If the cattle owls were located for several years in a row near trees or springs, the latter are called untouchables, as places where the Orë-s rest (Tirta, 2004). If people ruined their resting place, then the Orë-s could harm them. The Orë-s are called "The Goods of the Mountain" in Labëri region in south Albania or "Zana" in the north. 
Another cult is that of some creatures of nature (Tirta, 2004), which had specific attributes of holiness, such as the wild goat, designated the deity of the forest; sorkadhja or roe deer which according to beliefs, had been human (cries with tears and makes human gestures) and addressed the Sun with prayer; the eagle, which, if killed, can be used for prosperity in walnut production; the bee, which was described as having once been human; the wolf, who, according to superstition, was protected by St. Martin, who also assigned pets to eat. The wolf's skin or tooth was used as a talisman for children or the horse so as not to catch the evil eye. According to beliefs, the wolf had initially been the dog that ate a lamb after the lady sat down to rest from exhaustion. The curl was also described as a being of supernatural and auspicious qualities. She was thought to have been a woman and had enjoyed pulling fur with a fork. In order not to harm the cattle, the people of that time put a fork with a plume of wool and bread with cheese. The swamp bush or big bull sang to tell the time if it would be good or bad.

Another ancient cult is the cult of the Sun (Tirta, 2004), which was also part of the agricultural and livestock cults, that of fire and hearth, mountains, etc. Also, other cults were those of the Moon and stars. Albanians prayed and swore in the name of these cults. Based on the cult of the Sun, the activity of the people of that time was regulated. For example, the girl had to get married in the early morning sun to be lucky in married life. Summer Day was also, according to Indo-European mythology, to give more power to the Sun, to bring summer faster, vegetation in nature, and abundance in productivity. In popular beliefs, we find the image of the Moon as a woman and the Sun as a man, similar to the beliefs of Indo-European peoples. Also, the Moon appears as connected with Zana, with virgin nature, i.e., as the deity of nature and as the protector of women (Tirta, 2004). In connection with the cult of the Sun, there was the cult of some high places or mountain peaks that were worshiped with prayers before the Sun rose.

Another cult was that of stone and caves (Tirta, 2004). Some types of stones were valued as unique, as bearers of supernatural features. To this genus of the cult also belonged the beliefs about unique rocks, mountain peaks, caves, and passages, which were places where the people of that time offered gifts or sacrifices. There have also been instances of the worship of mythical stones or stone murals dedicated to people who have died violently. Throwing stones at these places makes spiritual sense. Also, people who threw stones at these places were expected to have health and prosperity in family life. There are many cases of places of worship called the Holy Stone (as in Puka, etc.). This is evident in the mythical legends, pilgrimages, and gifts of the past in these places.

Another cult is that of magical rites (Tirta, 2004). For example, in the Living Stone, located in the Tetovo Highlands, women went to seek healing for themselves and to strive for the lives of their children. The stone was also used in oaths, covenants, or other decisions of certain rural communities. Also, in the highlands, stones were used 
to divide and redefine the forgotten borders between two families or villages, especially for forests, groves, and pastures. In this case, people swore on a stone. Some other types of stones, called lightning bolts, were considered sacred after falling from the sky. These were meteor remnants. Elsewhere in the world, the places where these meteor stones are located have been turned into places of pilgrimage, such as the Black Stone of Mecca. The Beja performed on the lightning stones was very strong. These types of stones were also used to protect themselves from the evil eye, as they hung on the body of cattle or pregnant women. Megaliths, which are massive stones placed in the graves of the dead, were considered the materialization of their souls.

Another cult, part of Albanian mythology, is the snake (Tirta, 2004), which was present in every place both on earth and underground. On the one hand, he appears as an ordinary being, and on the other hand, he appears as a sacred being, i.e., with supernatural properties. The serpent of the house was called bollë, or the horn of the house. According to popular belief, the serpent was a dominating force of land and underground. For this reason, in some parts of Northern Albania, it had become taboo. His murder was a disaster for the man. This was also related to the need for soil fertility. The skin or head of the snake was considered auspicious for the house. The snake was seen as a living thing strongly associated with home and family, as it was considered their protector. If the house snake is killed, disasters occur in people, livestock, etc. It was thought that every house without exception had its own snake, without which the house could have no progress either in people or in wealth. Even when the house was abandoned, the snake stayed there, as there is no land without its snake. Belief in snakes was another notable aspect of this cult (Tirta, 2004). Also, according to popular belief, he was considered auspicious with healing qualities, which had to do with the magical practices of that time. It was also used as a talisman to protect children from the evil eye. The snake is also present in the artistic creativity of the people. On the one hand, he was presented as a symbol of evil and, on the other, as a protector of good. He can turn into a little girl if Kreshnik saves her from burning. As a reward, it gives strength to face opponents. In the Songs of the Kreshniks, the serpent appears as a healer of Muji's wounds. Even the Kreshniks, known as dragons in popular belief, were thought to derive their power from one or more snakes that were inside their bellies. There are cases when the snake was also described as a Kuçedër that hurt people. Its drowning by man was regarded as a victory over the savage forces of nature.

As for the cults of family life, we distinguish some of them. The mother of the hearth (Tirta, 2004) is associated with the cult of the hearth or fire. This cult displayed both positive and negative traits. Witch women are the ones who eat people and drink their blood. According to another image, the Mother of Hearth decides the child's fate on the third night after birth. "Mothers of the Hearth" because they ate food, where to be treated well by people. They often baked a cake without dough, which was placed in the new hearth of the house. Another cult of family life is that of the doorstep (Tirta, 2004). According to the beliefs, water should not be drunk on the doorstep at night 
because the orë-s or angels could send slaps, etc. Also, the door sill should not be hopped on but crossed, as it was the burial place of the first of the family. Therefore, bars or horseshoes were placed on the doors.

The cult of the woman's breast was used for the prosperity of the home in people and wealth (Tirta, 2004). It was noticed that some old stone houses had carved women's breasts in their facades, such as in Dukagjini, etc. Also, the Beja on the mother's breasts has been powerful among the highlanders. When an older woman who had left many descendants died, the latter kissed her chest before burying her, an action which symbolized the preservation of the memory of the continuation of generations by the mother. Also, the legend of the wall testifies to the existence of the cult of the woman's chest among Albanians. The mother's breast walled in the castle, on the bridge or other objects, never runs out and gives strength and endurance to this object. Also, in the Legend of Muji and Halil, the Orë (mountain fairies) make Muji powerful with three drops of breast milk.

\section{Death in rites and beliefs}

The spiritual life of our people contains a set of myths, rites, and beliefs about death, the dead, ancestors, graves, etc. They are related to the ceremonial practices of death as well as to calendar holidays, people's affairs, prosperity, or misfortunes in life. We distinguish the mourning or lamentation of men as a phenomenon with very ancient origins. Women usually mourn with laws or verses. They cry out loud, while men cry out loud. However, in the case of calamities, at least five people up to 80 or more join in, a chief judge is appointed, who directs the calamity or may be performed by a solitary man on the way to the house of the deceased, home or to the graves.

Women's mournings, especially in Malësia, are accompanied by crying and screaming, hair pulling, etc. It was believed that the dead ate, drank, heard, saw, felt, and spoke like the living. Thus, when he hears grief, he is glad that they are honoring him (Tirta, 2004). It was also believed that the man who was in agony would not have lost his soul if he did not have the people he had remembered before he died. If people are there to say goodbye or honor him, he leaves in peace.

Popular beliefs about death and the dead linked earthly life to the afterlife. For example, in the Albanian Legendary Epos, when they open the tomb to exhume Muji, they find him cross-legged in the tomb (Tirta, 2004, p. 229). In the Medieval Epic and the ballads, there are cases when certain people return from this life to perform a task and go back to that life, such as in the Song of Dhoqina. The dead were raised to supernatural proportions. Respect and love were expressed for them in order for them to bring prosperity and not misfortune. Also, other rites are performed to get the land better, as she had to accept the dead in her bosom nobly. One tradition that has survived to the present day is to throw three punches to and from the dead so that the earth may be easy for the corpse. According to the beliefs, the man who had committed many sins, even the earth, could not stand inside. He was described as a wolf who harmed people and livestock. 
Rituals about the dead show respect for him, his deification, but also the fear of him or death. For example, the cutting of the nails of the dead is explained by the fact that since he worked during his life with his hands, that is, with his nails, he would have left pieces of earth and blessings, which must be cleaned, so that he does not suffer fate and prosperity of the house in the tomb. Memorial dinners and lunches as an apology to the dead can also be considered as a feast attended by the dead (Tirta, 2004, p. 233).

\section{Mythical beings}

Part of Albanian mythology are many mythical beings or demons, such as the Fairy and the Holy Shepherd, who were considered as deities of nature, Kuçedra, who was the personification of destructive forces in nature and in human life, the Dragon, who was the protective deity of human communities from the actions of the Kuçedra, Ora, which was a protective deity of man or communities of people, Vitorja (Snake of the House), which was a protective deity of the house and the land of residence, etc. (Tirta, 2004, p. 111). Two of the most intriguing figures of the myth in Albanian legends are the mountain crafts and "Ora," a half-ghost and half-human figure who could protect them or cause you disaster if he appeared to the people of that time. According to the myth, the Orë was a transparent shapeless figure which could be transformed into a human body in some instances. It is believed that an "Ora" lived in the mountains, forests, springs near the places where people lived.

The figure of the Fairy was attributed to the properties of a mountain deity, which protected vegetation and wildlife. Also, by means of supernatural powers, she fought to the aid of the knights or heroes of the country. Thus, this figure occupies an essential place in the legendary medieval epic of the Albanians. In popular beliefs, she appears as a girl of perfect beauty, dressed in traditional local bridal gowns (Tirta, 2004 , p. 113). She lived in the middle of a sacred, dense forest or in a cave where people could not cross. It was also believed that they had their frosts or rested in fresh wells, on rocks, or on top of the mountains. Crafts were carriers of the divine forces of healing and rescuing people from danger. In case the Fairies are disturbed, or people degrade their virgin nature, then they appear as wild and as enemies of people, causing them disability and death. Mentioning the name of these deities was considered a grave sin, so people addressed them with the words: "Shtojzavalle," "Mira (the good one)," "Bardha (White)", etc.

Two other figures of the popular Albanian faiths are Dragoi and Kuçedra, who, despite being enemies between them, are seen as inseparable from each other. In fairy tales, Kuçedra is presented with a set of attributes. It has two possible forms, either that of a large monster or snake or that of a turtle, eel, lizard, or frog (Tirta, 2004, p. 123). If the snake or bolla has not been seen by anyone for three years or more, it turns into Kuçedër. The latter takes the nutrients of the village. As it grows and thickens, its skin is scratched through rocks and rocks polluting the water of the wells. It was thought that Kuçedra had his head on the top of the mountain and his feet on the sea. It could 
stop the water of springs or lakes, and for that, the Dragons had to drown it. Kuçedër could also be an old, tall woman who was thought to have been born into families that had broken the crown within three vertical generations. There were cases when Kuçedra was considered as an absorber of nutritional products and prosperity for the village. It is presented both as the deity of the underworld and as the deity of the sky, as it causes floods but also brings drought. In case she died, she was no longer sacrificed, like people or cattle. The examination of mythological phenomena, rites, practices, mythical beings, beliefs related to different cults is an expression of the psychology of the people, as well as the historical-social organization. They lived until the first half of the century. XX, and to some extent even today in Albania, as well as in other Balkan and European countries. Myths have created the ground for the further development of Albanian literature.

\section{The connection between mythology and literature}

There is a very close connection between literature and mythology, as the latter has been one of the fundamental spiritual pillars of man and society. Myths have been an integral part of human life because he has always aimed to penetrate or explain unknown phenomena. Over time, myths became an integral part of literature. For some studies, all literature comes from myth and turns into myth (Buzhala, 2019). The presence of this mythological subject in Albanian literary creativity highlights the great importance that mythology has had in this literature from its beginnings until today.

The connection between myth and Albanian literature is evident in the recontextualization of the myth of the authors, such as Ernest Koliqi, Fan Noli, Mitrush Kuteli, Ismail Kadare, Rexhep Qosja, etc. and other names, from the beginnings of Albanian literature until today. They used the material taken from the myths to adapt to local culture and mentality. According to Sabri Hamiti (Buzhala, 2019), Albanian culture, literature, is a culture of opposition, which continually preserves the western mythological and literary bases, but also the seal of its authenticity. According to this author, literature is related to myth as a narrative universality, as well as the places where the story begins to be structured in literary forms. According to him, themes as cultural resources are based on ancient myths or the universality of human life. These topics are:

"People: Sacrifice, Besa (oath), Revenge; Historical Renaissance: Illyrians, Skanderbeg, Ali Pasha, Literature of the League of Prizren: The Holy Bridge, Ago Ymeri, The Stream of Constantine and Doruntina: Daily Life, Permanent Exile: Albanian Language, Renaissance, Hero, Anthem. "(Isufaj, 2003, p. 34).

Like the literature of other countries, our literature, in its beginnings, remains closely connected with mythology and folklore. These mythological and folkloric creations have served as models, themes, and sources of various subjects and motifs. Themes borrowed from religious mythologies, the Bible and the Qur'an, the sacred histories of Christianity and Islam, as well as for Albanian legends and traditions, occupy an 
important place in ancient Albanian literature. Combining religious myths with artistic reality, the writings of Albanian authors are sometimes mythological and sometimes stripped of religion and utilitarian function, becoming earthlier, as in the case of the mourning of St. Mary presented by P. Budi, the cry of which sounds like that of an ordinary mother, expressing grief for the loss of her child.

Elements of religious mythology and folklore are also present in the writings of humanists. They are attached to the historical truths unfolded in these works. We find such elements in "The Siege of Shkodra" and "History of Skanderbeg," where in addition to historical truths, miraculous events are presented as acceptable, the action of divine forces is accepted, religious feelings are believed. Thus, truth is mixed with legends, myths, and traditions. For example, when Barleti testifies about the origin of the Albanians, he connects it with legends and myths since the Iron Age. Also, when he claims that Skanderbeg's mother had dreamed of being pregnant, it was of a mythological dimension because, according to this dream, she was associated with a dragon so large that it covered almost all of Epirus (Buzhala, 2019).

When a panoramic view of Albanian literature of the XIX century and the first half of the $\mathrm{XX}$ century is given, we notice the presence and dominance of the romantic spirit with many creations. Along with romantic breaths, the authors of this period can also create myths, which are the result of the isolation of this historical figure (like Skanderbeg), geographical space (like Mount Tomorri), or living creatures (like eagles). Using the figure and name of the national hero, Skanderbeg, the authors gradually turned him into a symbol, a myth. Moreover, thus, their creative visions were close to those of the European Romantics, who also turned into myths the essential personalities of their time.

In general, Albanian authors of romanticism were inclined towards folkloric models to show the authenticity of national life. Addressing folklore, De Rada and G. Dara, in their writings, exploited the great wealth of Albanian mythology. One such example is P. Vasa's novel "Bardha e Temalit" (Vasa, 1999, p. 31), in which the environment is not only a background for events but also a means of creating a romantic work atmosphere.

In an attempt to create the romantic ideal, the authors used the function and power of dreams as a mythical model. De Rada, G. Dara, P. Vasa, etc., gave considerable space to dreams, thus bringing a kind of romantic thought with features of mythological poetic thought. Thus, their heroes find themselves between reality and dreams. These authors, at the same time, exploited the poetic figuration of mythological origin that had been preserved and refined within the Arbëresh people, such as the Dragon, the shadows of the night, the figures of witches, the warning signs, and the dreams.

In Fishta's work, a creative play appears through glorification and sarcasm. He presents the sorrows and wounds of the inhabitants of his country, which aim to be a model that is passed on to generations. From text to text, myth is powerfully combined with the real world, with geography and mentality, to gain artistic eternity. 
"Lahuta e Malcisë" (1923) highlights various national myths, among the most prominent, as the myth of mountaineering, as well as the myth of mountains, based on the canonical code, the myth of blood, and honor, which is the legality and life of the inhabitants of these mountains. Also, the most beloved figure of those lands, the Albanian woman, who symbolizes honesty and loyalty, turns into a myth by this author.

Even Koliqi does not neglect the canon and the laws of Albanian life, sometimes because of myths, and sometimes overturning them, in the case when the subjects of his works confront them, as a mixture of cultures. Meanwhile, he brings back the myth of Narcissus as an Albanian variant of this mythical figure. On the other hand, we find Fan Noli among the myths, which sometimes include biblical myths, sometimes constructs a personal myth as autobiographical memory.

Migjeni, feeling and perceiving the 'absences' of the individual, tends to perpetuate them in art. Thus, the object of his writings is the breaking of existing myths and the introduction of new myths. Migjeni, by building his hero, actually constructs the myth of the hypocrisy of modern civilization. The presence of demystifying and allegorical values become dominant in his writings, focusing on the confusion of feelings, various confrontations of extremes, such as village-town confrontation, small man-big man, etc. However, when he creates myths, he tends to turn the old myth into a new myth. For, Migjen subjected the mythical subject taken from antiquity to living matter. As a narrator, Kuteli stood out like no other author, with the stamp of originality and creative individuality. Relying more on the tradition of our popular prose, the author did not follow any other pattern of narrative but simply brought this existing pattern into a new form. At almost every level of storytelling, Kuteli's writings relate to people telling stories, characters, functionality, details, and so on. Usually, the main weight is left to the narrator, but without breaking the connection between the reader and the hero.

Kuteli has a significant influence on popular creativity. Nasho Jorgaqi says:

"Without leaving aside the tradition of Albanian literature, a fan of Naim and Noli, but also a deep connoisseur of foreign literature, Kuteli consciously relied mainly on the models and artistic experience of people and gave his physiognomy" (Jorgaqi, 2007, p. 52).

Referring mainly to the model of storytelling, Kuteli offers a strange reality, where different worlds coexist, where fairies kidnap people, they celebrate the creators of pagan holidays, appear to people and scare the sick, people seek hidden treasures in scary caves, where non-earthly beings appear, the dead take part in the feast, the living visit the world of the dead, marry among themselves and have children, and so on. Moreover, this reality comes from Kuteli's pen as a result of his attraction to Albanian mythology. In the world of myth, we have no adaptation to a familiar experience. On the contrary, myth is an imitation of actions near or within the possible limits of desire (Fraj, 1990). Moreover, this mythical presence comes naturally, 
without strains and impositions. More like a writer's necessity. "To say that the writer needs myths is a sign of the need he feels to join a society, to find its place in it," says R. Wellek and A. Warren (1994).

Even in later authors, such as Kadare, Qosja, Pashku, Camaj, etc., it is noticed that myths are part of their writings.

"Aesthetic archaism, myth, and mythical symbolism with many layers are all illustrated in Camaj's work. The myth of Camaj is an exploration of a millennial culture, which supports history and emerges as a union of past and future through the mentality of a 'pure Albanian' according to the scholar V. Isufaj (2003, p. 36).

On the other hand, K. Trebeshina is inclined to destroy the myth and create an antimyth through the degradation of the myth, satirical, stinging, nihilistic tones (Buzhala, 2019).

\section{Conclusions}

The above examples and many others show the close connection between myth and Albanian literature. Myth lies at the heart of literature. It is the premise of the genesis and paradigm of fiction and, at the same time, of all literary books together. Scholars inevitably deal with myth variations when studying literature, and myths themselves have been deeply explored by various anthropologists and literary critics. The interrelated study of literature and myth, along with the unwritten norms passed down from generation to generation, testifies to the psychology and culture of the Albanian people over the years.

The connection between myth and Albanian literature is evident in the recontextualization of the myth of the authors, such as Ernest Koliqi, Fan Noli, Mitrush Kuteli, Ismail Kadare, Rexhep Qosja, etc. and other names, from the beginnings of Albanian literature until today. They used the material taken from the myths to adapt to local culture and mentality. Albanian culture and literature is a long tradition of opposition, which continually preserves the western mythological and literary bases, but also the seal of its authenticity. Literature is related to myths as a narrative universality, as well as the places where the story begins to be structured in literary forms, while themes as cultural resources are based on ancient myths or the universality of human life. 


\section{Bibliography}

[1] Bonnefoy, Y. (1993). American, African, and Old European mythologies. University of Chicago Press.

[2] Buzhala, S. (2019). The Influence of Myth on Albanian Literature. Acta Universitatis Danubius. Communicatio, 13(2). Retrieved from https://dj.univdanubius.ro/index.php/AUDC/article/view/33/251

[3] Doja, A. (2005). Mythology and Destiny. Anthropos, 100(2), pp. 449-462. https://doi.org/10.5771/0257-9774-2005-2-449

[4] Elsie, R. (1994). Albanian Folktales and Legends. Tirana: Naim Frashëri.

[5] Elsie, R. (2001). A Dictionary of Albanian Religion, Mythology and Folk Culture. London: Hurst \& Company.

[6] Fishta, Gj. (1937). Lahuta e Malcisë. Shkodra: Franciscan Printing House.

[7] Fraj, N. (1990). Anatomia e Kritikës. Prishtina: Rilindja, p. 188.

[8] Georges R. \& Jones M. O. (1995). Folkloristics: An Introduction. Bloomington: Indiana University Press, p. 1.

[9] Isufaj, V. (2003). Rikthimi i Mitit në Veprën e Kadaresë. Tirana: Onufri.

[10] Jorgaqi, N. (2007). Mitrush Kuteli në 100-vjetorin e lindjes. Prishtina: Akademia e Shkencave dhe e Arteve të Kosovës \& Tirana: Akademia e Shkencave të Shqipërisë, p. 52.

[11] Misiri, L. (2015). Myth and Antimyth in the Fictions of Socialist Realism in Albania. European Journal of Language and Literature Studies Articles, Vol. 1. Retrieved from https://ideas.repec.org/a/eur/ejlsjr/26.html

[12] Tirta M. (2004). Mitologjia ndër shqiptarë. Tirana: Akademia e Shkencave e Shqipërisë.

[13] Tirta, M. \& Bezhani, P. (2004). Mitologjia ndër shqiptarë. Tirana: Mësonjëtorja.

[14] Vasa, P. (1991). Bardha e Temalit. Tirana: Mësonjëtorja e Parë, p. 31.

[15] Wellek, R. \& Warren, A. (1994). Teoria e Letërsisë. Tirana: Shtëpia Botuese Encikopedike,p. 181. 